\title{
UTILIZATION POSSIBILITIES OF TIMBER WASTES IN LEATHER
} MANUFACTURING

\author{
CIGDEM KILICARISLAN OZKAN, SINA POURRASOUL SARDROUDI, ARIFE CANDAS \\ ADIGUZEL ZENGIN*, GOKHAN ZENGIN, HUSEYIN ATA KARAVANA, BEHZAT ORAL \\ BITLISLI \\ Ege University, Faculty of Engineering, Leather Engineering Department, 35100, Bornova, \\ Izmir/Turkey, cigdem.kilicarislan@ege.edu.tr, pourrasoul9984@gmail.com, \\ gokhan.zengin@ege.edu.tr, husevin.ata.karavana@ege.edu.tr,oral.bitlisli@ege.edu.tr \\ *Corresponding Author E-mail: candas.adiguzel@ege.edu.tr
}

\begin{abstract}
In timber production, only the $24 \%$ of trees could be turned into timber and used as an end product, while the rest becomes the waste of forest goods. Although it is known that the wastes of timbers are utilized in different fields such as energy and composites production in general, their use in the leather industry as a tanning material is seemed to be a new concept. For this purpose, the usage possibilities of the timber wastes of red and black pine in the form of sawdust and bark were aimed to investigate for the leather manufacturing. The red and black pine wastes were extracted at Koch extractor at $90^{\circ} \mathrm{C}$ for $8 \mathrm{~h}$ and the tannin contents, influences on the shrinkage temperature, filling properties and final physical characteristics of the leathers such as tensile strength, elongation at break, tear strength and color measurements were investigated. The results revealed that the red pine barks (Pinus resinosa L.) could be an alternative source of vegetable tannins compared to other timber wastes for the leather industry due to the better extraction yield and tannin content. Besides similar results in terms of tanning properties were obtained with the commonly used vegetable tannins such as valonea and mimosa.
\end{abstract}

Keywords: timber waste, red pine, leather tanning

\section{INTRODUCTION}

Timber wood wastes are disposed of directly to landfill due to the lack of processing and this amount is approximately reached to two-third of the timber production (Taylor and Warnken, 2008). Solid forest wastes that create pollution are tree barks, chip and sawdust as well as sludge and coal ash. The forest industry wastes in general are organic and they can be used as a raw material in the field of energy (fuel), agriculture and composites production (Engür and Kartal, 2001).

The wood wastes have phenolic compounds and polymers which release bioinhibitory phenols, terpenes and tannins during decomposition (Martin, 1998). In the view of these findings, the phenolic compounds in wood-based wastes seem to be an alternative source of vegetable tannins for the leather manufacturing depending on their tannin contents and extraction yields. Although there are several vegetable tannins having polyphenolic characteristics used in tanning and retanning processes in leather production, mimosa, quebracho, sumac, tara, valonea and chestnut are the most important tannins that are commercially available for the leather industry (Kilicarislan et al., 2015).

In this study, the utilization possibilities of the timber wastes of red and black pine in the form of sawdust and bark were aimed to investigate for leather manufacturing. After the extraction of red and black pine wastes at Koch extractor at $90^{\circ} \mathrm{C}$ for $8 \mathrm{~h}$, the tannin contents, extraction yields and tanning properties of the extracts were determined. The pickled sheep skins were used for the tanning operation and the shrinkage temperatures, filling coefficients and physical properties of the leathers were investigated. 


\section{MATERIALS AND METHODS}

\section{Materials}

The sawdust and barks of red and black pine were obtained from timber companies in Izmir/Turkey. The barks of red and black pine were crushed to 5-10 $\mathrm{mm}$ pieces before extraction process to ensure an increase in the extraction yields.

Pickled sheep skins used in tanning trials were supplied from Tezcan Leather Company in Uşak/Turkey. The conventional chemicals were used in the leather production. Commercially available mimosa and valonea were used as the control tannins.

\section{Methods}

\section{Determination of the Moisture Content}

The moisture contents of the timber wastes were determined according to SLC 113. All experiments were carried out in triplicates and the results were given as an average value.

\section{Extraction of Timber Wastes}

Timber wastes $(100 \mathrm{~g})$ were soaked in $700 \mathrm{ml}$ distilled water in a clean glass beaker and maintained for one day to make the soaking easier. Then, timber wastes were subjected to extraction process at $90^{\circ} \mathrm{C}$ for $8 \mathrm{~h}$ at Koch extractor. High extraction temperature and long extraction time were preferred to obtain higher extraction yields. The yield of extraction was calculated according to Equation (1).

Yield $=[($ Extract obtained $(\mathrm{g}) /$ Amount of gallnuts used $(\mathrm{g})] \times 100$

\section{Tannin Analysis of the Extracts}

The total solid matters, total soluble matters, non-tannin constituents and tannin matters absorbable by hide powder of extracts were determined according to SLC 114, 115,116 and 117, respectively. Triplicate analyses were performed and the results were given as a mean value.

\section{Tanning Procedure}

After the tannin content determination of the extract solutions, the sheep skins were tanned with the extract solutions that contain $13 \%$ of active matter. The extract solutions were introduced to pelts in three batches according to the recipe given in Table 1. The vegetable tanning by the use of valonea and mimosa were similarly performed for the control group. The powder forms of mimosa and valonea with the active tanning matter of $13 \%$ were selected.

Table 1. Tanning procedure

\begin{tabular}{lccccc}
\hline Process & Amount $(\%)$ & Product & Temp $\left({ }^{\circ} \mathrm{C}\right)$ & Time(Min.) & $\mathrm{pH}$ \\
\hline Depickle & 300 & Water $7-8^{\circ} \mathrm{Be}$ & $28-30$ & 10 & \\
& 1 & $\mathrm{HCOONa}$ & & $30(15 * 2)$ & \\
& $\mathrm{x}$ & $\mathrm{NaHCO}_{3}$ & & 90 & $4.5-5$ \\
\hline
\end{tabular}

https://doi.org/10.24264/icams-2018.XI.8 
ICAMS $2018-7^{\text {th }}$ International Conference on Advanced Materials and Systems

\begin{tabular}{|c|c|c|c|c|c|}
\hline Process & Amount $(\%)$ & Product & $\operatorname{Temp}\left({ }^{\circ} \mathrm{C}\right)$ & Time(Min.) & $\mathrm{pH}$ \\
\hline \multirow[t]{2}{*}{ Bating } & 100 & Water & \multirow[t]{2}{*}{35} & \multirow[t]{2}{*}{30} & \\
\hline & 1 & Acidic bating enzyme & & & \\
\hline Washing & 100 & Water & $25-28$ & 15 & \\
\hline Degreasing & 3 & Degreasing agent & $30-35$ & 30 & \\
\hline Washing & 100 & Water $3^{\circ} \mathrm{Be}$ & & 10 & \\
\hline Washing & 100 & Water $3^{\circ} \mathrm{Be}$ & & 10 & \\
\hline Washing & 100 & Water $3^{\circ} \mathrm{Be}$ & & 10 & \\
\hline \multirow[t]{12}{*}{ Tanning } & 2 & Dispersing syntan & \multirow[t]{11}{*}{30} & 20 & \\
\hline & $\mathrm{x}$ & Extract solution & & 30 & \\
\hline & 1 & Synthetic fatliquor & & 20 & \\
\hline & $\mathrm{x}$ & Extract solution & & 30 & \\
\hline & 1 & Synthetic fatliquor & & 20 & \\
\hline & $\mathrm{x}$ & Extract solution & & 30 & \\
\hline & 1 & Dispersing syntan & & 20 & \\
\hline & 1 & Synthetic fatliquor & & 20 & \\
\hline & 1 & Combination of & & 15 & \\
\hline & & Sulfochlorinated Synthetic & & & \\
\hline & & Paraffin and Emulsifiers & & & \\
\hline & 0.2 & Fungicide & & 20 & \\
\hline \multirow[t]{2}{*}{ Fixation } & 1.2 & $\mathrm{HCOOH}$ & & 60 & 3.5 \\
\hline & & Washing \& Draining & & & \\
\hline \multirow[t]{3}{*}{ Neutralization } & 150 & Water & \multirow[t]{3}{*}{$30-35$} & & \\
\hline & 1 & HCOONa & & 30 & \\
\hline & $\mathrm{x}$ & $\mathrm{NaHCO}_{3}$ & & 60 & $5-5.5$ \\
\hline \multirow{5}{*}{ Fatliquoring } & $80-100$ & Water & \multirow[t]{5}{*}{$40-45$} & & \\
\hline & 2 & Synthetic fatliquor & & & \\
\hline & 1 & Sulphited fish oil & & & \\
\hline & 2 & Synthetic sulphonated fatliquor & & 60 & \\
\hline & $\mathrm{x}$ & $\mathrm{HCOOH}$ & & $30-45$ & $3.8-4$ \\
\hline
\end{tabular}

Determination of Shrinkage Temperature and Filling Coefficient of the Leathers

The tanning properties of the leathers were evaluated according to the shrinkage temperatures and filling coefficients. In order to investigate the filling properties of the tannins, the thicknesses of de-pickled pelts $\left(\mathrm{T}_{\mathrm{i}}\right)$ and tanned leathers $\left(\mathrm{T}_{\mathrm{e}}\right)$ were measured in the wet form by using a thickness gauge. Filling coefficients were calculated according to the following Equation (2).

Filling coefficient $\%=\left(\left(\mathrm{T}_{\mathrm{e}}-\mathrm{T}_{\mathrm{i}}\right) / \mathrm{T}_{\mathrm{i}}\right) \times 100$

The shrinkage temperatures of the leathers were determined according to IUP 16 .

\section{Determination of the Physical Properties}

The leathers were conditioned before physical tests at $23 \pm 2^{\circ} \mathrm{C}$ and $50 \pm 5 \%$ relative humidity for $48 \mathrm{~h}$ according to TS EN ISO 2419.

The thicknesses of the leathers were measured with SATRA Thickness Gauge according to TS EN ISO 2589.

The tensile strength and percentage of elongation at break of the leathers were tested according to TS EN ISO 3376. The tear load of leathers was determined according to TS EN ISO 3377-1 Part 1: Single edge tear and TS EN ISO 3377-2 Part 2: Double edge 
tear standard methods. All physical tests were performed by Shimadzu AG-IS Tensile Tester and Trapezium-2 software. Three horizontal and vertical samples were tested and the results were given as an average value.

\section{Color Measurements}

The color of the leathers was evaluated by Minolta Spherical spectrophotometer by the use of CIE*Lab system. 20 different measurements were performed for the each leather sample and the results were given as a mean value.

\section{RESULTS AND DISCUSSIONS}

\section{Moisture Content of Timber Wastes}

Average moisture contents of red and black pine sawdust were found to be $5.72 \%$ and $15.03 \%$, while the mean moisture values of their barks were determined as $14.12 \%$ and $11.31 \%$, respectively.

\section{Extraction Yields and Tannin Contents of Timber Wastes}

Extraction yield represents the percentage of obtained total solid matter at the end of extraction process and it is a crucial parameter as well as the tannin contents of the extracts. Because the low-yielded extract solution with high tannin content does not seem to be efficient in the use of tanning process. The extraction yields and tannin contents of the timber wastes are given in Table 2 .

Table 2. The extraction yields and tannin contents of the timber wastes

\begin{tabular}{llcc}
\hline & & Extraction Yields (\%) & Tannin Contents (\%) \\
\hline Red pine & Sawdust & 1.91 & 50.21 \\
& Bark & 25.14 & 60.47 \\
Black Pine & Sawdust & 2.22 & 39.37 \\
& Bark & 1.94 & 7.82 \\
\hline
\end{tabular}

The results of tannin analysis showed that the barks of red pine had higher extraction yield and tannin content as $25.14 \%$ and $60.47 \%$ respectively.

Although the tannin contents of red and black pine sawdust were relatively high, the extraction yields were found considerable low. These results indicate that the extraction process must be repeated for many times in the use of tanning operation in addition to high energy, source and time consumption. Therefore only the extract of red pine barks was found favorable for the tanning experiments.

\section{Tanning Properties of the Leathers}

The shrinkage temperatures and filling coefficients of the leathers are given in Table 3. Considering the results of filling coefficient, it was observed that the fullness properties of the leathers tanned with extract solution were appropriate. The shrinkage temperature of the leathers tanned with extract solution was found lower than the control leathers, although it is very common shrinkage temperature of the vegetable leathers $\left(75-85^{\circ} \mathrm{C}\right)$. 
Table 3. Filling coefficients and shrinkage temperatures of the leathers

\begin{tabular}{lcc}
\hline & Filling Coefficients $(\%)$ & Shrinkage temperatures $\left({ }^{\circ} \mathrm{C}\right)$ \\
\hline Red pine bark extract & 30.4 & 75.1 \\
Valonea & 26.9 & 83.3 \\
Mimosa & 58.5 & 85.0 \\
\hline
\end{tabular}

\section{Physical Strengths of Tanned Leathers}

The physical strengths of leathers are given in Table 4 . The percentage of elongation results were found similar, but the tensile strength of the leathers tanned with red pine bark extract was found appreciably higher than the control leathers. The single and double edge tear strength results showed that the leathers tanned with red pine bark extract and mimosa were gave similar characteristics in contrast to leathers tanned with valonea. The tensile and tear strength properties of the leathers were found adequate in accordance with UNIDO acceptable leather qualities.

Table 4. Physical test results of the leathers

\begin{tabular}{lcccc}
\hline & $\begin{array}{c}\text { Tensile } \\
\text { strength } \\
\left(\mathrm{N} / \mathrm{mm}^{2}\right)\end{array}$ & $\begin{array}{c}\text { Elongation } \\
(\%)\end{array}$ & $\begin{array}{c}\text { Single edge tear } \\
\text { strength/ thickness } \\
(\mathrm{N}) /(\mathrm{mm})\end{array}$ & $\begin{array}{c}\text { Double edge tear } \\
\text { strength/ thickness } \\
(\mathrm{N}) /(\mathrm{mm})\end{array}$ \\
\hline Red pine bark & 23.8 & 73.8 & $28.5 / 0.98$ & $66.7 / 1.04$ \\
Valonea & 18.0 & 72.7 & $22.1 / 0.82$ & $46.8 / 0.87$ \\
Mimosa & 14.8 & 73.4 & $29.9 / 1.65$ & $60.8 / 1.65$ \\
\hline
\end{tabular}

\section{Color Measurements of the Leathers}

The color difference between the leathers was determined by calculating $\Delta \mathrm{E}$ value (Equation 3).

$\Delta \mathrm{E}^{2}=(\Delta \mathrm{L})^{2}+(\Delta \mathrm{a})^{2}+(\Delta \mathrm{b})^{2}$

The increase in $\Delta \mathrm{E}$ indicates an increase in color difference. The $\mathrm{L}, \mathrm{a}, \mathrm{b}$ values are shown in Table 5.

Table 5. Color measurement values of the leathers

\begin{tabular}{lccccccc}
\hline & $\mathrm{L}$ & $\mathrm{a}$ & $\mathrm{b}$ & $\mathrm{dL}$ & $\mathrm{da}$ & $\mathrm{db}$ & $\mathrm{dE}$ \\
\hline Red pine bark & 63.99 & 12.96 & 26.79 & -34.92 & 13.07 & 27.14 & 46.22 \\
Valonea & 63.09 & 5.95 & 22.63 & -35.81 & 6.06 & 22.97 & 43.07 \\
Mimosa & 60.00 & 10.87 & 17.64 & -38.91 & 10.98 & 17.99 & 44.35 \\
\hline
\end{tabular}

The $\Delta \mathrm{E}$ results of the leathers revealed that there is a color difference due to the different characteristics of the vegetable tannins. A and b values (represent the red and yellow color respectively) of the leathers tanned with red pine bark extract are determined higher than the valonea and mimosa tanned leathers. Although red pine extract and valonea gave similar lightness value, mimosa tanned leathers lead to a slight decrease in lightness value. 


\section{CONCLUSION}

In the present study, the utilization possibilities of the timber wastes of red and black pine in the form of sawdust and bark were aimed to investigate and following conclusions have been drawn;

a. Only the extract of red pine bark had sufficient extraction yield and tannin content.

b. The extract of red pine bark gave higher filling properties than valonea, but mimosa had the highest value.

c. The similar and higher shrinkage temperature values were obtained from the leathers tanned with valonea and mimosa.

d. The red pine bark extract provided higher physical characteristics to leathers.

e. Consequently, it can be revealed that the extract of red pine barks can be used as a tanning agent in leather industry.

\section{Acknowledgements}

The authors would like to thank the Ege University Scientific Research Project Department Directorate, (Project No: 17MUH001) for financial support and Tezcan Leather (Uşak, Turkey) for providing pickled sheep skins.

\section{REFERENCES}

Engür, M.O. and Kartal, S.N. (2001), “Orman Ürünleri Endüstrisinde Çevre Kirliligi ve Kontrolü”, İstanbul Üniversitesi Orman Fakültesi Dergisi, 51(2), 43-52.

Kilicarislan Ozkan, C., Ozgunay, H. and Kalender, D. (2015), "Determination of Antioxidant Properties of Commonly Used Vegetable Tannins and Their Effects on Prevention of Cr(VI) Formation", Journal of the Society of Leather Technologists and Chemists, 99(5), 245-249.

Martin, A.M. (1998), "Bioconversion of Waste Materials to Industrial Products", in: Martin A.M. (ed), Springer Science +Business Media, LLC, 160, https://doi.org/10.1007/978-1-4615-5821-7.

Taylor, J. and Warnken, M. (2008), "Wood Recovery and Recycling: A Source Book for Australia", Forest \& Wood Products Australia, 11.

Official Methods and Analysis (1996), SLC-113 Determination of Moisture, Society of Leather Technologists and Chemists.

Official Methods of Analysis (1996), SLC-114 Determination of Total Solids, Society of Leather Technologists and Chemists.

Official Methods of Analysis (1996), SLC-115 Determination of Total Solubles, Society of Leather Technologists and Chemists.

Official Methods of Analysis (1996), SLC-116 Determination of Non-Tannin Constituents, Society of Leather Technologists and Chemists.

Official Methods of Analysis (1996), SLC-117 Determination of Tannin Matter Absorbable By Hide Powder, Society of Leather Technologists and Chemists.

Official Methods and Analysis (2002), IUP 16, Measurement of Shrinkage Temperature up to $100^{\circ} \mathrm{C}$.

TS EN ISO 2419 (2012), Leather - Physical and mechanical tests - Sample preparation and conditioning.

TS EN ISO 2589 (2016), Leather - Physical and mechanical tests - Determination of thickness.

TS EN ISO 3376 (2012), Leather - Physical and mechanical tests - Determination of tensile strength and percentage extension.

TS EN ISO 3377-1 (2012), Leather - Physical and mechanical tests - Determination of tear load - Part 1: Single edge tear.

TS EN ISO 3377-2 (2016), Leather - Physical and mechanical tests - Determination of tear load - Part 2: Double edge tear.

UNIDO (1996), Acceptable Quality Standards in the Leather and Footwear Industry. Vienna, Austria: United Nations Industrial Development Organization. 